\title{
Global marine bacterial diversity peaks at high latitudes in winter
}

Joshua Ladau, Thomas J Sharpton, Mariel M Finucane, Guillaume Jospin, Steven W Kembel, James O’Dwyer, Alexander F Koeppel, Jessica L Green and Katherine S Pollard

The ISME Journal (2013) 7, 1876; doi:10.1038/ismej.2013.76

Correction to: The ISME Journal (2013) 7, 1669-1677; doi:10.1038/ismej.2013.37; published online 21 March 2013

Since the online publication of this article, the authors have noticed that a supplementary file has not been included with the paper.
The supplementary file (Supplementary file 4) has now been included, and appears alongside the online version of the original article.

The authors would like to apologize for any inconvenience this may have caused.

\section{Genetic diversity in cultured and wild marine cyanomyoviruses reveals phosphorus stress as a strong selective agent}

\author{
Libusha Kelly, Huiming Ding, Katherine H Huang, Marcia S Osburne and \\ Sallie W Chisholm
}

The ISME Journal (2013) 7, 1876; doi:10.1038/ismej.2013.92

Correction to: The ISME Journal (2013) 7, 1827-1841; doi:10.1038/ismej.2013.58; published online 9 May 2013

Since the publication of this article, the authors have noticed an error on page 2, concerning the following sentence: Our analysis does not include the highly divergent T4-like cyanomyovirus described recently by Sabehi et al. (2012) as it was not available when we began the work.

The correct sentence should include the word 'non' between 'divergent' and 'T4', and should read as follows: Our analysis does not include the highly divergent non-T4-like cyanomyovirus described recently by Sabehi et al. (2012) as it was not available when we began the work.

The error has now been rectified, and the correct article appears in this issue. The html and online pdf versions have also been rectified, and now carry the correct paper.

The Authors would like to apologize for any inconvenience this may have caused. 